\title{
The spectre of historical crop losses: Challenging questions and methodological issues
}

ANA ISABEl QUeIroz, Inês GoMes \& InÊS AMORIM

KEYWORDS: environmental history, climatic events, crop losses, plant pests, disasters.

JEL CODES: N50, Q51, Q54, R11.

\footnotetext{
alamities in agricultural production have emerged as a relevant research topic for global food security in the current context of adaptation to climate change. Historians have been participating in this research by examining crop losses in the past. However, they face challenging questions and methodological issues when evaluating the magnitude, intensity and social relevance of damages caused by adverse climate events and plant pests and diseases.

This paper presents a review of some aspects that lead to harvest failures, along with three case studies involving Portuguese territories in modern times, based on the scientific interest and research of the authors. A few methodological considerations are also provided concerning decryption and the use of available data, to help avoid misinterpretations in future research on the topic.
} 


\section{O espectro da perda de culturas na História: Problemas e metodologias}

\section{PALAVRAS-CHAVE: história ambiental, eventos climáticos, perda de colheitas, pragas agrícolas, desastres.}

\section{CLASSIFICAÇÃO JEL: N50, Q51, Q54, R11.}

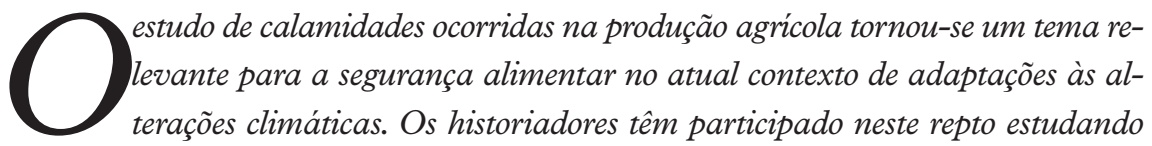
as perdas de colheitas no passado, enfrentando, todavia, múltiplos desafios e problemas metodológicos na avaliação da magnitude, intensidade e relevância social dos danos causados por eventos climáticos adversos, invasões por pragas ou doenças de plantas.

Este artigo de revisão apresenta alguns fatores que conduzem a perdas de colheitas, e três estudos de caso, ocorridos em território português durante o período contemporâneo, resultantes do interesse científico e da investigação das autores. Tecem-se algumas considerações sobre a utilização da informação disponível, por forma a evitar interpretações incorretas em futuras investigações sobre este tópico.

Received: 2019-06-02 - Revised: 2019-12-11 - Accepted: 2019-12-17

Ana Isabel Queiroz [orcid.org/0000-0002-0246-2626] is fellow researcher at the IHC - NOVA FCSH (Institute of Contemporary History), Lisboa (Portugal) and CIDEHUS (Interdisciplinary Research on History, Cultures and Societies), University of Évora (Portugal).E-mail: queirozanaisabel19@gmail.com

Inês Gomes [orcid.org/0000-0001-9210-9959] is a Post-doc Researcher at the Centro de Estudos Interdisciplinares do Século XX da Universidade de Coimbra - CEIS20, Instituto de Investigação Interdisciplinar - IIIUC, University of Coimbra (Portugal). Address: Rua Filipe Simões n. ${ }^{\circ} 33,3000-186$ Coimbra (Portugal).E-mail: gomes.ida@gmail.com

Inês Amorim [orcid.org/0000-0002-3649-8256] is Professor of Early and Modern Economic and Social History at the University of Porto (Portugal), researcher of CITCEM. Address: Department of History and Political and International Studies,Via Panorâmica, s/n, 4150-564 (Portugal).E-mail: iamorim@letras.up.pt 


\section{INTRODUCTION}

Harvests are paybacks for the farmers continued effort on land management. Growers expect to obtain enough food to feed their families, and crop sales constitute their annual income and an opportunity for some monetary liquidity. In the past, the harvest yields also allowed peasants to accomplish their annual manorial dues. Any crop loss was perceived as a calamity ${ }^{1}$.

A crop loss means -and meant- reduction in quantity and/or quality of yield that could occur before the harvesting or during the post-harvest storage (Oerke, 1999: 77). Crop losses had severe impacts on food prices, as well as on total production values and national economies. They also had serious consequences in the social (e.g. unemployment, aggravation of inequalities, poverty and hunger, migration), and environmental (e.g. land abandonment, land use and landscape changes) domains.

Agriculture failures were as devastating in the past as they are today. Scientists suggest that climate and plant pests are some of the main reasons behind major losses. The increasing frequency of extreme climatic events all over the world and the new invasive plant pests and diseases are key concerns for developed and developing regions. Floods, storms, droughts and heatwaves were particularly notorious and drastic in the last few decades (Wallemacq, 2018). Recently, the debate takes into account the relationship between temperature, population growth and metabolic rates of insects and how the warming climate scenario can result in present and future crop losses. Severe disturbances can occur in temperate regions, where most of the grain is produced (Deutsch et al., 2018).

In this regard, numerous actions have been taken by international organizations in recent times. The 1990s were declared the International Decade for Natural Disaster Reduction of the United Nations and the first decade of the new century the United Nations (UN) were focused on the International Strategy for Disaster Reduction ${ }^{2}$. The first two goals of the UN Sustainable Development Agenda for 2030 are linked to food shortages: eradicating poverty and "zero hunger". Strategies are, for instance, being developed to fight certain plant pest species. The Food and Agricultural Organization of the United Nations (FAO) maintains a Desert locust watch to [help] build a world without hunger ${ }^{3}$.

1. From the Latin calamitās, which means "loss", "damage", "harm", "misfortune", "disaster", "blight" or "crop failure" (calamus means "reed").

2. United Nations Office for Disaster Risk Reduction (UNISDR) website: https://www.unisdr.org/ who-we-are/history [Consulted on 5 January 2019].

3. Locust watch. Desert Locust. Food and Agriculture Organisation of the United Nations (FAO) 
Each time locusts invade rural areas, swarms drastically damage vegetation, causing severe threats to crops and aggravating food scarcity. At the European level, for example, the European Plant Protection Organization (EPPO) pursues its objectives in 52 countries, protecting plants by developing international strategies against the introduction and spread of pests which are a threat to agriculture, forestry and the environment, and by promoting safe and effective pest control methods ${ }^{4}$. The European Union (EU) also addresses climate catastrophes in its territory through a specific body called Emergency Response Coordination Centre (ERCC) and also convenes humanitarian support to people living in dire situations outside its borders ${ }^{5}$. Furthermore, many other international institutions are concerned about extreme weather events and their frequency (very high temperature, torrential rains, and droughts besides the regulation of rain seasonality, which drastically affects agricultural production (Rosenzweig et al., 2001). The Intergovernmental Panel on Climate Change (IPCC) recommends land related actions to contribute to climate change adaptation, mitigation and sustainable development, taking in consideration the site-specific nature of climate change impacts on food system components and wide variations in agroecosystems [...] linked to environmental and cultural context at regional and local levels ${ }^{6}$

Within academia, interdisciplinary approaches address the historical phenomena of crop losses (in their natural and geographical dynamics) and, simultaneously, its social impacts (with economic, political and cultural consequences). By analysing several dimensions, those studies do not focus on a strict economic reading, instead looking into the complexity behind human-nature relationships. In this framework, environmental history deals with critical questions on this subject: how people faced calamities, how decisions about prevention and mitigation were taken and how communities adapted to the "risks" and "challenges of nature" over time. As Christof Mauch (2009: 6) wrote in this regard: [h] istorians have at their disposal a set of methodological tools that enables them to reflect the entire scope of human interaction with nature, including political and institutional ram-

website: http://www.fao.org/ag/locusts/en/info/info/index.html [Consulted on 5 January 2019].

4. European and Mediterranean Plant Protection Organisation website: https://www.eppo.int/

5. In 2018, for example, a budget of 47 million was granted to help 2 million Afghans who had been affected by the drought, with 1.4 million in immediate need of food assistance. European Civil Protection and Humanitarian Aid Operations, European Commission website: https:/ec.europa.eu/ echo/news/eu-scales-humanitarian-support-afghanistan-worst-drought-decades-looms-large_en [Consulted on 5 January 2019].

6. 2019 IPCC Special Report on Climate Change, Desertification, Land Degradation, Sustainable Land Management, Food Security, and Greenhouse gas fluxes in Terrestrial Ecosystems. Summary for Policymakers, p. 20. https://www.ipcc.ch/site/assets/uploads/2019/08/4.-SPM_Approved_Microsite_FINAL.pdf 
ifications, socially produced perceptions, and historically variable anxieties, as well as social and economic damage. Nevertheless, fragmentary data and recorded narratives from these past events are often the only memory reaching the present. Knowledge of past crop losses is then dealing with a few challenges.

This paper open a monograph dedicated to "Crop losses: historicizing plant pests and climate events", which compiles five contributions presented in a plenary session on the theme "Crop losses" in the International Conference Transitions in Agriculture and Rural Society, held in Santiago de Compostela, in June 2018. It brought together researchers that studied the topic in a historical perspective and its impacts on rural societies, who shared and discussed their methodological experience and outcomes, taking both cultural and environmental facets in account. This first text is thus introductory, summarizing some methodological aspects for the study of the impact of environmental drivers on agricultural production. Through particular examples, sources and interpretations, it addresses research on historical calamities and how their impacts have been assessed or inferred, at least in the Western World.

The article first brings up how and why climatic, plant pests or diseases events led to harvest failures. Second, three case studies on crop losses in Portuguese territories in modern times from the authors own scientific interest and research are explored: rice cultivation and its vulnerability to water balance; the Coccus invasion in the Azorean orange groves (1840s-1860s); and the first years of the phylloxera crisis in the Douro vineyards (1870-80). Finally, and the foremost contribution, it discusses difficulties and challenges of researching the topic from a historical point of view providing a few considerations about the use of available data and on avoiding misinterpretations in future research on calamities and agricultural production.

\section{DRIVERS OF CROP LOSSES}

\subsection{Climatic events}

Liam Brunt (2004) concluded that the effect of the climate was the most relevant element in explaining the level of English wheat yields in the Industrial Revolution times ${ }^{7}$. Conversely, soil quality had a limited role. Clover and increased manuring, which have been

7. The author summarises environmental variables (rainfall, temperature, day length, sunlight, soil type) and artificial variables (fertilizer, seed variety, cultivation techniques) estimating wheat production yields in relation to these aspects. 
seen in literature as one of the reasons for the growing agricultural productivity in England (Bath, 1960; Allen, 2003), had, apparently, fewer benefits ${ }^{8}$.

A new understanding of climate change in long periods (e.g. long Ice Ages and Warm periods) and shorter climate fluctuations has enable or disable the cultivation of plants and the pasturing of livestock, may have influenced decisions about abandoning or planting new areas. Recognising the influence of climate in the course of history forces historians to rethink adaptation and the agricultural limits of certain types of plantations in certain places. That dependence on non-human environmental conditions highlights the risks to food production experienced in areas exposed frequently and severely to weather disasters, such as droughts, floods, frosts, heatwaves, torrential rains or summer rains (White, Brooke \& Pfister, 2018). Nevertheless, climate effects and the resilience of societies must be analysed together, to avoid climate determinism and simplistic causality (OliverSmith, 1999) ${ }^{9}$. Frameworks that explain how natural disasters affect people, thus recommend a joint interpretation of nature and society to understand and be able to do something to prevent or mitigate calamities (Bankoff, Frerks \& Hilhorst, 2008). In fact, the current nature-culture approaches reveal a complex dialectic between climate and society. The state control, market, collective institutions, households and property rights, for instance, must also be considered for the direct "disaster-focused" measures (Bavel \& Curtis, 2016), to evaluate if the events of a certain established regularity or predictability became harmful or if they aggravated an earlier state of weakness (Bankoff, 2003).

In the last few decades, the means and evaluation methods used to create a link between food subsistence crises and climate represented a great research challenge. Geographers and climatologists have given more attention to climate constraints than historians. Still, the few references obtained in the most recent general work on climate (Pfister et al., 2018) recommended more efforts to promote research based on historical information, in order to get a critical reconstruction of serial data. At the core of an environmental history enquiry is the evaluation of how agriculture was driven by climate conditions. Crop losses and hunger, however, may not have a linear correlation. Food deprivation is not only dependent on environmental factors but also conditioned by multiple political, social and cultural features. In line with the seminal book Poverty and Famines: An Essay on Entitlement and Deprivation (Sen, 1981), modern famines have

8. Besides technology, these authors emphasise the role of land quality and its geomorphological position, population distribution, land property, market, energy, knowledge, connections with capitals, markets and consumption.

9. About the debate in relation to climate indicators and impacts on crop losses, see e. g. Post (1973) and CAREY (2014). 
been explained by unnatural origins. Actually, many scientists accept that low production might not be the sole reason for food scarcity (several examples in Alfani \& Ó Grada, 2017). For instance, a flood, successive floods or flash floods can have terrible consequences in terms of mortality, loss of property, etc., however, in the short-term, their incidence may not necessarily have a direct impact on agricultural production ${ }^{10}$. Indirectly, these events may lead to interruptions in the supply of food, due to difficulties in accessing and distributing food or warning about preventive measures, and in the performance of public actions (Blaikie et al., 2005; Thorndycraft et al., 2003; Weintritt, 2009; Barca, 2010).

\subsection{Plant pests and diseases}

Regarding the impact of insects on crops, scientists point out: [a]ccurate estimates of agricultural losses [...] are difficult to obtain because the damage caused by these organisms depends on a number of factors related to environmental conditions, the plant species being cultivated, the socioeconomic conditions of farmers, and the level of technology used (Oliveira et al., 2014: 50). These biophysical, ecological and cultural complexities do not deny the fact that farmers have faced countless insect outbreaks, other pest surges and diseases affecting all sorts of plants and crops.

Applied Entomology, as a science, goes back to the end of the eighteen century, despite records of injurious insects that affected crop losses since the old Greek writers ( $e$. $g$. Herodotus, Pliny and others) and the prophet Joel in the Bible. Economic Entomology, which rose in the 1850 s, allowed several experts and practitioners to develop research in official departments of European countries and their empire territories, and in the United States of America (Anonymous, 1910; Anonymous, 1936). Their main aims were the control and mitigation of plant pests and avoiding damages caused by an extensive sort of bugs, flies, cochineals, caterpillars, aphids, ants, etc. The expansion and technological improvement of agriculture, and the expectation of an increase in production were contradicted by the spread of many noxious organisms: the phylloxera's worldwide invasion of vineyards was only one case.

Continued losses in food commodities, mainly cereals and potatoes, were considered major causes of hunger throughout modern history. For example, the blight that extensively destroyed potato crops in several European countries from 1846 to the 1850 s was

10. Conversely, in many parts of the world, floods are a normal and essential component of the regeneration of crops, plant and aquatic life. 
a crucial factor in triggering food shortages that [led] directly to excess of mortality from starvation or hunger-induced diseases in several countries (Ó Grada, 2009: 4), namely in Ireland and the Netherlands (Ó Grada, 2017; Curtis et al., 2017). The emergence of this disease brought a new understanding of famine not as a regional or national phenomenon but as a pan-national calamity (Hoyle, 2017). A massive population loss (deaths by starvation, low nuptiality and birth rate) resulted, in fact, from a combination of economic backwardness, an ecological shock and an inadequate and, many would argue, callous official response (Ó Grada, 2017: 175).

Locusts swarms, for instance, were a persistent and a feared presence in the central and south cereal production areas of the Iberian Peninsula, at least from the end of the nineteenth century to the middle of the twentieth century (Gomes, Queiroz \& Alves, 2019) leading to the creation of a Locust Extinction Service (Serviço de Extinção dos Acrídios) in Portugal mainly to fight the common Moroccan locust Dociostaurus maroccanus ${ }^{11}$. Other locust species caused serious problems in different geographies. The Desert locust Schistocerca gregaria have not been taken into account when trying to understand the complexity of famine in Syria and Palestine during the First World War. Zachary J. Foster (2015) attributed the death of 100,00-200,000 people, who died from starvation or starvation-related diseases in the year immediately following the locust invasion, in which fruits, vegetables, fodder and a small but not insignificant amount of cereals were devoured, to this pest.

Europe also feared the Colorado potato beetle because of the devastation it caused in the US during the 1860s and 1870s. Due to its impacts on agriculture, during the Second World War, both the British and the Nazis feared its use as a weapon. An intentional release of insects in their potato fields could cause famines and deaths. Research was carried out to defend from possible attacks (Lockwood, 2009). However, in the late 1940s, the insect was widespread, and its damages to the fragile economy of the post-war were severe.

\section{CASE-STUDIES OF CROP LOSSES IN THE PAST}

The following case studies were selected upon the scientific and research interest of the authors. They show the typical challenges faced on evaluation crop losses in the past and illustrate methodological concerns raised by the availability of historical sources and their integration and interpretation.

11. About agricultural pests in Spain, see AzCÁRATE (1996). 


\subsection{Farming waters: Rice and climate before $1930 \mathrm{~s}$}

Rice is more common in Asia, Africa and America than in Europe with a long and diverse history of the widespread cultivation at a global scale (Bray et al., 2015). In Portugal, it was introduced either from Africa or from China in the early sixteenth century (Gilbert, 2015) and nowadays has the highest consumption per capita in all of Europe (16 kg/year), about three times above the European average (Fraga, Guimarães \& Santos, 2019).

The cultivated area has remained very restricted for centuries due to ecological reasons. In the Portuguese case, particularly (from north to south) in Vouga, Mondego, Tejo and Sado river basins and estuarine marsh, rice grown under irrigated conditions depends on abundant and regular water reserves, and is particularly sensitive to the amount and seasonal distribution of precipitation as well as floods and droughts. For rice cultivation, water availability is crucial in the summer, a period in which plants' maintenance needs large amounts of running water due to high temperatures. Furthermore, drainage is required to remove the excess of water during the cereal maturity period in August and September (Ribeiro, Lautensach \& Daveau, 1987; Borges, 2014) ${ }^{12}$.

Rice cultivation suffered from droughts and floods, at different times. An extreme rainfall during the harvest period with harmful consequences was recorded in the beginning of the nineteenth century (Telles, 1800). In the following decades, the rice "spikelet" was the main cultivated variety of the species Oryza sativa, which flowers have a glume bract and needs abundant and regular waters. Nevertheless, people were concerned with losses in dry periods and also cultivated different variety without glume, which demands less water, named by the farmers as Carolino. With the plantation of both varieties, the total cultivated area expanded. In 1854-55, it was 3,362 hectares and the production rose to 127,915 hectolitres. In the same period, the annual consumption was around $2 \mathrm{~kg}$ per capita. This information is part of a report (Corvo, Almeida \& Ribeiro, 1860) about the rice cultivation in Portugal, which was crucial to examine the extreme vulnerability of rice production. It recommended an innovative system of ditches and flooded trays for controlling the higher salt percentage and oxygen deprivation of rice roots in stagnant waters, underlining the success of draining systems. These new processes and practices had

12. Climatic factors such as temperature, solar radiation and wind also have an influence on the yield of rice as they affect the growth of the plant and the physiological processes related to grain formation (Sustainable Rice Systems in FAO website: http://www.fao.org/agriculture/crops/thematic-sitemap/theme/spi/scpi-home/managing-ecosystems/sustainable-rice-systems/en/), which are hardly available for the historical remote periods. 
already been encouraged some years before by some local and regional authorities in 1856 (Vaquinhas, 1996).

The report recommended the mandatory reuse of rice fields in particular in the area of Lisbon by improving a system of reabsorption of deposited water. Describing the Tagus fields, the text noticed the waterlogged after rice harvests due to lack of ditches and drainage points. It proposed the implementation of a drainage system not only for public health reasons (that is, the risk of malaria) but also for profitability. The advised technological input was only implemented in the first decade of the twentieth century, after a cycle of torrential floods and health problems, during a period of excessive rainfall from 1875 to 1919 (Melo, 2017; Alcoforado, 1984). In fact, this improvement could explain the impact on rice production recorded in the period of 1900-30 compared to the previous (Table 1). In a context of agricultural development in the country, the rice output was three times higher than those of wheat.

TABLE 1

Agricultural output growth by product (percentage)

\begin{tabular}{lcccc}
\hline & wheat & maize & rye & rice \\
\hline $1870-1900$ & 1.10 & 0.48 & 1.89 & -1.87 \\
$1900-1930$ & 1.83 & -1.11 & -1.06 & 3.11 \\
\hline
\end{tabular}

Source: Branco and Silva (2017).

\subsection{Sweet oranges in the Azores (1840s-1860s)}

Orange groves were the main source of economic income of the Azorean elites in the nineteenth century (Miranda, 1989; Dias, 1995; Queiroz \& Alves, 2019). John W. Webster (1821) and the brothers Joseph and Henry Bullar (1841), among other visitors, described the beautiful landscape of the islands, praising the fruits, the gardens, the orangeries and other plantations. The brown soft scale (Coccus hesperidum) was introduced in the Azores at the end of the 1830s. When the pest spread through the archipelago (islands of Faial, S. Miguel, S. Jorge and Terceira) its impact was described as a calamity. 
FIGURE 1

\section{Evolution of orange exports in the harbours of Horta (Faial)} and Ponta Delgada (S. Miguel), from 1833 to 1870

a) Horta

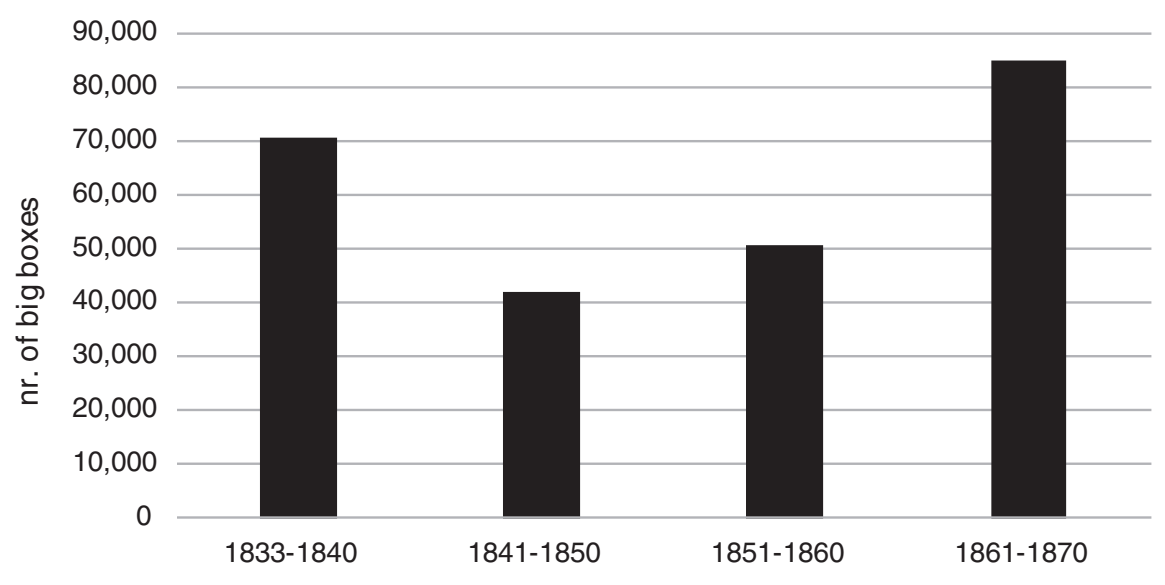

b) Ponta Delgada

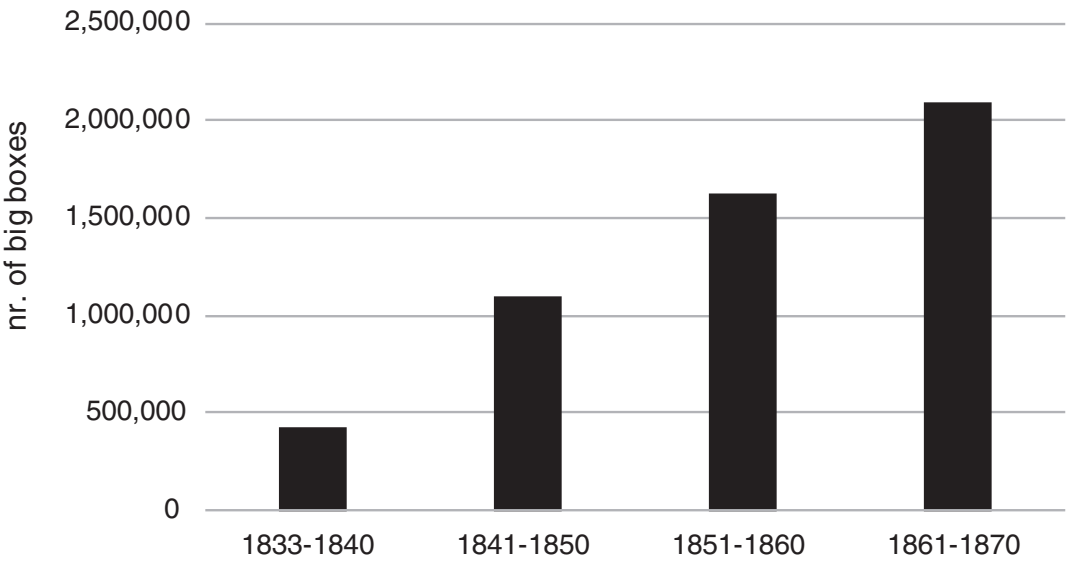

Source: Gil and Ribeiro (1874) apud Dias (1999).

In 1844, the Civil Governor estimated the total losses in the district of Horta, concluding that the insect had almost completely destroyed the orange groves ${ }^{13}$. In turn, one of

13. [...] a situação das laranjeiras, quase totalmente aniquiladas pelo verme, muito mais desenvolvido neste concelho e que ameaça a total destruição. Biblioteca Pública e Arquivo Regional João José da Graça-Horta, PT/BPARJJG/ACD/GCHRT/1840/03. "Rascunho do relatório apresentado pelo Governador Civil da Horta", 1 June, 1844. 
the most educated and reputable Azorean farmers described them differently: the island of Faial exported about 50 loads of oranges annually from its native orchards: [...] this year, not due to the harshness of the climate, or the seasonal storms, but due to the true devastation to which their farms were reduced, only exported 6 loads $^{14}$. Azorean representatives in the Chamber of the Gentlemen Deputies of the Portuguese Nation spoke about attacking the scourge with which Providence seems to want to punish those people ${ }^{15}$. The pest arrived at the more productive and valuable orchards of the island of S. Miguel and, for the first time in the Portuguese history, specific legislation concerning measures to face an agricultural pest was adopted (Law of February 1845, to be applied in the district of Ponta Delgada, S. Miguel). The invasion in S. Miguel was described in the subsequent years as a bitter experience ${ }^{16}$.

Speeches point to a dramatic situation with high losses for orange farmers and traders. Nevertheless, these statements should be confronted with orange export data from the Azorean harbours (Figure 1). In Horta (Faial), there was a decrease of c. $40 \%$ in the 1840 s, compared to the previous decade, which confirms the narratives. However, in Ponta Delgada (S. Miguel), exports increased continuously between the 1830s and 1860s, despite evidence that the pest had started in 1842 , questioning the severity of the economic losses described by the farmers and the authorities.

\subsection{Vines and wines in the Douro region (1860s onwards)}

The phylloxera (Daktulosphaira vitifoliae) was considered the worst of all plant pests, due to the losses it caused in the main wine regions around the world, after the species spread from its native range, in the nineteenth century. Portugal was the second European country to be invaded, after France (Martins, 1991). Damages were recorded since the 1860s, but general alarm reached the Porto wine producers and the national authorities during the following decade and thereafter. The fight against the pest would henceforth be re-

14. [...] a ilha do Faial exportava anualmente dos seus virentes pomares cerca de 50 cargas de laranja: [...] neste ano, não pelos rigores do tempo, ou intempérie das estações, mas pela verdadeira devastação a que ficaram reduzidas as suas quintas, apenas export [a] 6 cargas (CANTO, 1844).

15. [...] atalhar um flagelo com que a Providência parece querer castigar aqueles povos (Diário da Câmara dos Senhores Deputados, 11 December, 1844, p. 397). Created in 1826 with the Constitutional Charter, it was the lower house of the Cortes Gerais, the legislature of the Kingdom of Portugal during most of the constitutional monarchy. The Deputies were elected through direct suffrage of the electoral circuits corresponding to the districts of Portugal.

16. [...] experiência amarga (Anonymous, 1849). 
garded as a national endeavour (Macedo, 2012). Losses in wine production were highlighted in the discourse of politicians and farmers, who drew attention to the situation in the fields and wineries. Despite the number of historical sources mentioning the phylloxera, estimating economic losses is a challenge.

The first mention of the phylloxera in the Chamber of the Gentlemen Deputies of the Portuguese Nation dates back to $1873^{17}$. In this decade, the invasion spread in the Douro river basin (Vila Real district, where Porto wine is produced) reaching c. 4,200 hectares in 1877, which corresponded to 33,600 hectolitres (Soares, 1878). However, provisions concerning pest control were only adopted in 1879 . Then, the government estimated a total of 6,000 hectares of devastated vineyards and a decrease of 50,000 hectolitres in production ${ }^{18}$. The Opposition questioned these figures, hindering the adoption of a budgetary boost to control the pest in 1880 , referring that the damages in wine barrels ${ }^{19}$, amounted to less than $1,000^{20}$. Supporting the Government, another deputy mentioned a loss of 20,000 barrels $^{21}$.

The local councils were called upon to grant fiscal advantages or request financial support, with a discourse that stressed how the phylloxera invasion would cause unemployment $^{22}$, increasing emigration ${ }^{23}$ and hunger ${ }^{24}$.

The regional and national impacts of the phylloxera were barely seen in the statistics of wine production from 1870 onwards (Figure 2):

a) in the Vila Real district, there is no data for the last years of 1870s; nevertheless, a general increase in production was recorded comparing 1871-72 low productions with those of the triennial 1880-82, contradicting the discourse of landowners and politicians; these figures reveal that the break occurred in 1883 with a subsequent fast recovery;

17. Diário da Câmara dos Senhores Deputados, 12 February, 1873.

18. Diário da Câmara dos Senhores Deputados, 26 April, 1879, p. 1384.

19. Each barrel had the capacity of 534 litres.

20. Diário da Câmara dos Senhores Deputados, 26 April, 1879, p. 1385.

21. Diário da Câmara dos Senhores Deputados, 1 May, 1879, p. 1480.

22. Diário da Câmara dos Senhores Deputados, 17 March, 1891, p. 3.

23. Diário da Câmara dos Dignos Pares do Reino, 7 April, 1896, p. 321. The Chamber of the Most Worthy Peers of the Realm was the upper house of the Cortes Gerais, the legislature of the Kingdom of Portugal during most of the constitutional monarchy. Members of the Chamber were Peers of the Realm, appointed directly by the Portuguese monarch.

24. Diário da Câmara dos Senhores Deputados, 9 May, 1901, p. 34. 
b) in total, the general increase lasted until the middle of 1890 , when there was a decline, which was not related to the phylloxera but to the mildew invasion.

The increase in the figures of wine production may also be related to adulteration and falsification (Martins, 1996). In order to maintain profit, producers would mix the wine with water and brandy or sell wine from other regions as Douro wine.

\section{FIGURE 2}

Wine production in hectolitres, from 1870 to 1900

Vila Real district

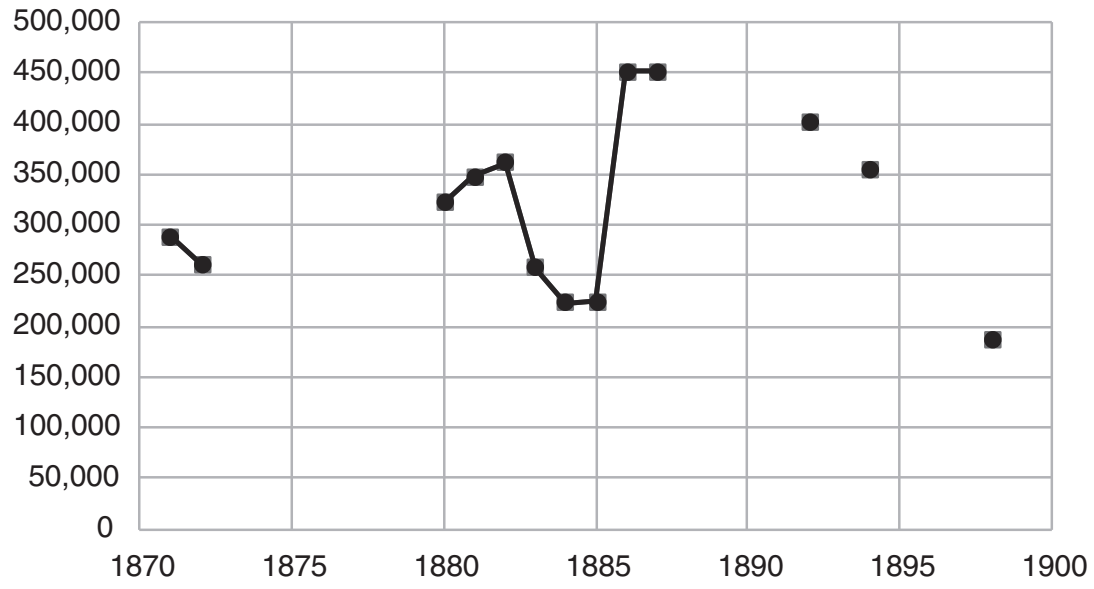

Total mainland Portugal

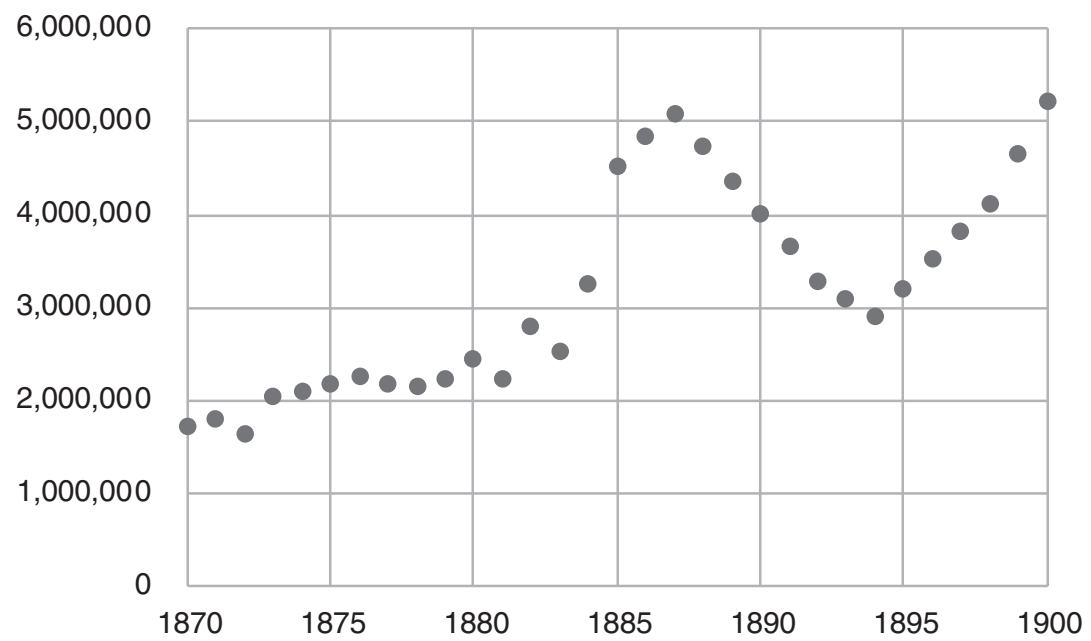

Sources: Agriculture in Portugal, 1870-2010, FCT-PTDC/HIS-HIS/122589/2010, 2015; Agricultural Regional Production, 1850-2010. Retrieved from http://www.ruralportugal.ics.ul.pt/data-files/ 


\section{DISCUSSION}

Historians face challenging questions and various issues when addressing past crop losses. Difficulties arise when trying to evaluate the magnitude, intensity and social relevance of the damages caused by adverse climatic events or invasions by plant pests and diseases, situations always socially considered or perceived as calamities. When historical narratives refer to losses in crops or their processing products (e.g. wine, olive oil), the descriptions are frequently vague and without quantification. In these circumstances, to what extent can empirical data support the assumption that climate, pests or diseases are responsible for agriculture failures? Regardless of their severity, calamities are widely regarded as an unpleasant or dangerous occurrence. Harvest failures are naturally real and have had known consequences throughout history.

\subsection{Inference from very poor information}

The lack of quantitative data and the reliance on qualitative information as a trustworthy source of knowledge on crop losses are the two major data-related problems. The amount of information necessary to access the damages and impact of calamities on crop yields is huge. As far as infestations are concerned, historical information is almost inexistent. Necessary data include estimates of crop distribution and value, pest distribution and average infestation level, and finally a damage function relating average infestation and crop yield (Koenning et al., 1999: 588). In turn, to analyse climate-related events and their effects on agriculture one needs complete data series on temperature, precipitation and humidity, which are only available from the nineteenth century onwards and within a limited geographical scope (Pfister et al., 2010; Camuffo et al., 2010). Natural sciences can answer historical questions when using palynological records. One report confirms that a succession of severe droughts occurred in the eastern Mediterranean for over a 150-year period, from $1250 \mathrm{BCE}$ to about $1100 \mathrm{BCE}$, which may have contributed to the disappearance of the Mycenaean culture in Greece, the Hittite Empire, the Egypt of the pharaohs, the copper-producing kingdom located on the island of Cyprus, the great trade emporium of Ugarit on the Syrian coast, and the Canaanite city-states under Egyptian hegemony (Langutt et al., 2015; Langutt, Finkelstein \& Litt, 2013). However, this kind of data is also scarce.

When accurate information is lacking both on agricultural production and on the drivers of crop losses, the relationship between phenomena seems impossible to establish. The case-study of rice in Portugal, for instance, shows that in the absence of quantitative records of crop losses along the nineteenth century, historians can infer that the losses had 
enough magnitude to trigger technological responses and the huge land investment carried out during the second half of the nineteenth century. In particular, extreme rain in harvest periods, considered a cause of floods and crop losses, led to a land management policy of damage prevention and investments in infrastructures that regulated flows and floods. The farming of waters can be seen as a history of resilience against local constraints in particular in the Tagus river edges. Without drainage works, the rice cultivation area and the resulting economic activity would not have expanded there (Martins, 1992, 2005), and elsewhere ${ }^{25}$.

\subsection{Incomplete and unreliable data}

Few and incomplete statistics on agricultural production, discrepancies and contradictions between different sources and the lack of accurate and reliable sources, as well as definitions, nomenclature and conversion factors between units, are other methodological concerns, even when records pinpoint a decrease in agricultural production and when a noxious agent is confirmed.

On the one hand, definitions of crop, yield or production, among other terms, may be different. The case of the phylloxera in the Douro region is paradigmatic in this sense: cultivated area, number of barrels or hectoliters were units used for defining losses and the quantities do not always correspond. Different units (affected area, production, monetary cost), are difficult to reconcile. On the other hand, the names used for harmful agents like viruses, bacteria, fungi or animals are also dissimilar over space and time, and the units to measure crop yields are often divergent. These differences prevent comparisons and a thorough knowledge of the impacts, revealing, paradoxically, contradictions, resulting from different perceptions and interpretations of the calamities' effects.

Unreliable data are also a challenge for studying food crises in the past. Using anthropic sources, descriptions of starvation resulting from food shortage are usually based on eyewitnesses. Chronicles and travellers' accounts, unpublished memoirs or church records, personal correspondence or newspaper articles, frequently describe important events occurring in a country or region, informing researchers of episodes of crop losses and consequent impacts. Part of them are highly speculative. As Pankhursts (1966: 96-7) puts it

25. In the Aveiro region, despite the healthiness of the rice fields and their relation to the spread of malaria, local elites defended their economic and social importance for journeymen employed in these works, see VieIRA (1984), LeITÃo (1906) and CARVAlHo (1912); in Coimbra, see MENDIA (1883) and VAQUINHAS (1996). 
on his study on the Great Ethiopian Famine of 1888-92: chronicles [...] usually do no more than report that a famine occurred, a few add a word or two of description. Other studies also call attention to issues and questions needing further discussion and research, revealing that is an inherently complex topic and, since climate-related events and plant pests and diseases often come together, it is difficult to evaluate the impact of every single aspect (Dias, 1981: 350).

In La Rioja (Spain), for example, the phylloxera invasion was one of the aspects that led to the poverty of this province's population (Garmo, 1975). Reports, however, were not based on "numbers" but on records of human misery which occurred as a direct result of the phylloxera invasion (Ibid.: 669), which, according to the authors of this study, is more indicative of the real impact of the attack than a recitation of devastated acreage and changes in the nature of cultivation (Ibid.: 669). To what extent can historians use this kind of records? Although the information available is scanty and it does not present a proper evaluation of the damages, it provides a portrait of deprivation and despair (Ibid.: 669).

Quantitative data, when available, are mostly composed by assumptions: [o] $n$ a global level, the relative paucity of information available, the irregular distribution and the varying quality of data add to the problems in compiling loss figures for the major cropping areas (Oerke, 1999: 72). Famine on theWind, a reference book on pest-caused famines, states that no one has ever estimated the monetary loss caused by the mildew in the nineteenth century. However, reasonable guess[es] [...] place it at about: fifty thousand million dollars, or about one-half that caused by the Phylloxera louse (Carefoot \& Sprott, 1969: 99). Figures are rather imprecise.

\subsection{False perceptions and the discourse of catastrophe}

Narratives on crop losses are filled with dramatic metaphors. Exaggerations can result from the farmers, merchants and even the authorities' loss of profit. As Sprenger notes, the dramatic descriptions [...] demonstrate the fear different groups had of insect plagues. Such narratives could also be used to back up claims for financial support, to legitimate public control measures, or to justify the publication of a pest control book. [...] However, regardless of the actual damages, the perception of insect plagues influenced the adoption of pest control measures (Sprenger, 2015: 530).

Private interests prevailed in the discourse about the phylloxera, for instance. The invasion was instrumental in obtaining economic (e.g. tax forgiveness) and political ad- 
vantages (e.g. strengthening or denigrating regional and local authorities).Vineyards were a source of investments, expectations and political attention (Pereira, 1989), especially in the Douro where the wine economy constituted the only nineteenth-century example of modern agricultural capitalism in Portugal (Macedo, 2011: 159). Representatives were personally implicated by the problem, as most of them were landowners and farmers by inheritance or family tradition, so it does not come as a surprise that their rhetoric of catastrophe overcame the agronomic and commercial reality recorded in other sources. Figures concerning damages were subject to political manipulation, so historians need to interpret them critically.

The case study on the brown soft scale also reveals incongruities, which do not come from the phenomenon itself but from the perception of its impact on the economy. The pest counteracted the high business expectations of the Azorean farmers, which may justify their histrionic discourses. However, the history of the Azorean brown soft scale alerts historians to the rhetorical pitfalls. The disparities between speeches and figures are not related to false perceptions regarding the disruptive phenomena, but to the local and national political contexts, the dynamics of land use and the commercial opportunities during this period (Queiroz \& Alves, 2019). How can one explain the increase in orange exports regardless of "evidence" of the pest? External trade was the driving force that encouraged farmers to maintain and even increase their orange groves, despite tremendous difficulties. Furthermore, farmers enlarged their plantations in response to the markets, which overall compensated for the previously devastated orchards, especially in the island of S. Miguel (Canto, 1843). The growth of the British market during the Industrial Revolution was crucial; the reduction of customs duties in 1853 and its abolition in March 1859 turned the orange business more and more profitable until its breakdown, for other reasons, in the following decades (Miranda, 1989).

Finally, in the rice case study, false perceptions and the discourse of catastrophe is associated with a nineteenth century literature focused on the extreme mortality and malaria illness associated to areas of rice production. This image overshadows the other face of a product that gains space in agricultural and industrial terms. Scattered indicators, at a local scale, show the growing of the areas of production due to the higher productivity and its increasing value as a commodity. The debates about the consequences of large-scale rice production during the beginning of twentieth century reveal the perplexity among physicians, politicians and local and central authorities regarding contradictory indicators linking rice production, malaria, mortality, poverty and higher levels of productivity. 


\section{FINAL REMARKS}

Although the study of crop losses in the past is relevant to environmental history, in general, and to rural studies, in particular, it raises methodological difficulties related to the variety and availability of sources (from natural or anthropic origin) and the interpretation of information, derived from direct observations and measurements or proxies.

To be able to use the available data and avoid misinterpretations, future research on calamities and agricultural production should take into account that the effects triggered by collective losses, perceived as a calamity, were frequently instrumental to accomplish a personal or group purpose in order to gain political or economic advantages. Passionate dialogues among politicians, experts, local elites and populations usually hamper the demands of an ecological and technical investment, not necessarily reflecting the extent of the calamity. Knowledge of commercial dynamics and opportunities -as well as other economic or social dimensions- is also essential to interpret quantitative data and to comprehend that figures are "imbued" with measures to mitigate those impacts. Research also has to deal with the damage scale: the description of the damages suffered does not often correspond to the values of agricultural production depicted. The study of calamities should, thus, go beyond the national and regional scale; local histories of crop losses can be more vivid and dramatic, and their study might better illuminate the relations between the actors (e.g. farmers, employees, merchants, authorities) and the ecological, economic and political dimensions of the incident.

Historicizing crop losses and their social, economic and ecological impact on societies requires a solid environmental literacy and full integration of material and immaterial elements in an interdisciplinary study of the relations of culture, technology and nature through time. Despite the extent of the researcher's positioning on how nature influences human affairs, climatology, agronomy, anthropology and history, among other disciplines, should contribute with their different practices and frameworks for analyzing evidences of harvest failures. Climatology states about the typical meteorological conditions of a certain place along an annual cycle, and what can be considered a deviation from the ordinary, usual, or expected weather. The agronomic knowledge is in the core of the research whenever it needs to be supported, among others features, by chemical and physical soil suitability, type of seeds, processes of sow, treat and reap, the seasonal needs of water and the live cycle of plants and their pests and diseases. Anthropology brings insights about human attitudes and the organization of social and cultural relations, elements for understanding how people perceived and evaluated failures and disasters. History and its practitioners deal with time as a fundamental attribute of situation or context of information. Doing so, they distinguish the causes and motives underlying the action, the lan- 
guage of the present and that of the agents of the past and the scientific understanding of the complex phenomena of climatic changes and bioinvasions. Furthermore, historians are familiar with social, political and economic hierarchies and the varied forms of affirmation of politicians, scientists, farmers and traders involved in the subject, and the ones that frequently have a voice about it. In addition, they critically analyse the documents supporting research, incorporating the concepts and thinking of those who preceded them.

A constellation of knowledge is a procedural and inquiry necessity but is not in itself a guarantee for finding full return from research. As it has been explained above, when information is scarce, uncertain or contradictory many questions stayed unanswered, specially those seeking deepness and objectivity. Knowing why yields failed in a given year of unfavourable weather would benefit from a knowledge of the means and extent of cultivated areas, for example. A disaster described in general can says little about the way different social groups perceived it and were affected, for example. Nevertheless, questions shaped by different disciplines, focusing on their own framework, certainly diversify views on a multifaceted and complex problem of evaluating crop losses in the past and counter hasty and simplistic explanations of those events.

Finally, rural and agrarian historians should bear in mind that changing natural habitats into cultivated fields and pastures, sometimes degrading soils and waters, continuously burning wood and fossil fuels, altering atmospheric composition and climate on a global scale, also act together in framing duration, frequency, intensity and magnitude of the so-called natural disasters causing crop losses. In fact, nature and human history are entangled, and these are "human-induced disasters" instead of natural disasters: such catastrophes are brought about by natural phenomena without obscuring their anthropogenic dimensions; they are commonly assumed as unpredictable outbreaks of elemental forces that have a sudden, destructive impact on human affairs because their multiple and complex causes and origins are not immediately understood by the people that suffer their consequences (Pfister, 2009: 17).

\section{ACKNOWLEDGEMENT}

This work was funded by FCT, the Portuguese Foundation for Science and Technology (UID/HIS/04209/2013, UID/HIS/00286/2013 and IF/00222/2013/CP1166/CT0001 and UIDB/00057/2020). It benefited greatly from a discussion which occured at the "Crop losses" plenary session - Transrural 2018, held in Santiago de Compostela. The authors also thank to the reviewers of Historia Agraria for their useful comments on the original text. 


\section{REFERENCES}

Alcoforado, M. J. (1984). Quelques remarques sur l'évolution seculaire des precipitations à Lisbonne. In A. DE B. Ferreira, M. J. Alcoforado \& D. DE B. Ferreira (Eds.), Três estudos de Geografia Física (região de Lisboa e Atlântico Oriental: Comunicações apresentadas a reuniões internacionais em 1984 (pp. 10-27). Lisboa: Centro de Estudos Geográficos/INIC.

Alfani, G. \& Ó GradA, C. (Eds.) (2017). Famine in European History. Cambridge/New York: Cambridge University Press.

Allen, R. C. (2003). Progress and Poverty in Early Modern Europe. The Economic History Review, 56 (3), 403-43. http://www.jstor.org/stable/3698570

Anonymous (1849). O Agricultor Micaelense, (June), 312-14.

AnONYmous (1910). American Economic Entomology. Nature, (83), 47.

ANONYMOUS (1936). Economic Entomology. Nature, (137), 219.

AzCÁrate, I. (1996). Plagas agrícolas y forestales en España en los siglos XVIII y XIX. Madrid: Ministerio de Agricultura, Pesca y Alimentación.

BANKofF, G. (2003).Vulnerability as a Measure of Change in Society. International fournal of Mass Emergencies and Disasters, 21 (2), 5-30. http://ijmed.org/articles/81/

Bankoff, G., Frerks, G. \& Hilhorst D. (Eds.) (2008). Mapping Vulnerability: Disasters, Development and People. London/New York: Earthscan.

BARCA, S. (2010). Enclosing Water: Nature and Political Economy in a Mediterranean Valley, 1796-1916. Cambridge: The White Horse Press.

BATH, S.van (1960). História agrária da Europa Ocidental (500-1850). Lisboa: Presença. BAVEL, B. van \& CurTis, D. (2016). Better Understanding Disasters by Better Using History: Systematically Using the Historical Record as One Way to Advance Research into Disasters. International Fournal of Mass Emergencies and Disasters, 34 (1), 143-69. http://www.ijmed.org/articles/695/

Blaikie, P., Wisner, B., Cannon, T. \& Davis, I. (2005). At Risk: Natural Hazards, People's Vulnerability and Disasters. London/New York: Routledge.

Borges, J. A. Z. A. (2014). Estudo de Novas Variedades de Arroz Carolino para o Baixo Mondego. PhD thesis. Coimbra: Instituto Escola Superior Agrária de Coimbra.

Branco, A. \& Silva, E. G. DA (2017). Growth, Institutional Change and Innovation, 1820-1930. In D. Freire \& P. LaINs (Eds.), An Agrarian History of Portugal, 10002000 Economic Development on the European Frontier (pp. 219-44). Leiden/Boston: Brill.

Bray, F., Coclanis, P. A., Fields-Black, E. L. \& SchäFER, D. (Eds.) (2015). Rice: Global Networks and New Histories. New York: Cambridge University Press. 
BRUNT, L. (2004). Nature or Nurture?: Explaining English WheatYields in the Industrial Revolution, c. 1770. The Fournal of Economic History, 64 (1), 193-225. http://www.jstor.org/stable/3874947

Bullar, J. \& Bullar, H. (1841). A Winter in the Azores and a Summer at the Baths of the Furnas. London: Voorst.

Camuffo, D., Bertolin, C., Barriendos, M., Dominguez-Castro, F., Cocheo, C., Enzi, S., Sghedoni, M., Valle, A., Garnier, E., Alcoforado, M.-J., Xoplaki, E., Luterbacher, J., Diodato, N., Maugeri, M., Nunes, M. F. \& Rodriguez, R. (2010). 500-Year Temperature Reconstruction in the Mediterranean Basin by Means of Documentary Data and Instrumental Observations. Climatic Change 101: 169-199.

CAnto, A. (1843). A laranja. O Agricultor Michaelense, (December), 30-2.

CANTO, J. DO (1844). Coccus hesperidum (Cochonilha das laranjeiras). O Agricultor Michaelense, (February), 68-9.

Carefoot, G. L. \& Sprott, E. R. (1969). Famine on the Wind: Plant Diseases and Human History. London: Angus \& Robertson.

Carey, M. (2014). Beyond Weather: The Culture and Politics of Climate History. In A. C. IsENBerg (Ed.), The Oxford Handbook of Environmental History (pp. 23-51). Oxford: Oxford University Press.

Carvalho, J.V. De (1912). Boletim da Direcção Geral da Agricultura: Monographia da freguezia rural de Ovar, concelho de Ovar, no districto de Aveiro. Coimbra: Imprensa da Universidade.

Corvo, A., AlmeidA, B. DE \& Ribeiro, M. J. (1860). Relatório sobre a cultura do arroz em Portugal e a sua influência na saúde pública. Lisboa: Imprensa Nacional.

Curtis, D., Dijkman, J., Lambrecht, T. \& Vanhaute, E. (2017). Low Countries. In G. Alfani \& C. Ó Grada (Eds.), Famine in European History (pp. 119-40). Cambridge/New York: Cambridge University Press.

Deutsch, C. A., Tewrsbury, J. J., Tigchelaar, M., Battisti, D. S., Merril, S. C., Huey, R. B. \& NAYLOR, R. L. (2018). Increase in Crop Losses to Insect Pests in Warming Climate. Science, 361 (6405), 916-19.

DiAs, F. S. (1995). A importância da "economia da laranja" no arquipélago dos Açores durante o século XIX. Arquipélago-História, 1 (2), 189-240.

DiAs, F. S. (1999). A importância da economia da laranja. In F. S. DiAs, Uma estratégia de sucesso numa economia periférica: A Casa Bensaúde e os Açores 1800-1870 (pp. 16069). Ponta Delgada: Ribeiro \& Caravana.

DiAs, J. R. (1981). Famine and Disease in the History of Angola c. 1830-1930. The fournal of African History, 22 (3), 349-78.

Foster, Z. J. (2015). The 1915 Locust Attack in Syria and Palestine and its Role in the Famine During the First World War. Middle Eastern Studies, 51 (3), 370-94. 
Fraga, H., Guimarães, N. \& Santos, J. A. (2019). Future Changes in Rice Bioclimatic Growing Conditions in Portugal. Agronomy fournal, 9 (11), 674.

Garmo, P. H. DE (1975). Poverty and Peasants in the Rioja 1883-1910. Agricultural History, 49 (4), 662-72.

Gil, A. \& Ribeiro, A. (1874). Almanach Insulano para Açores e Madeira: Estatístico, Histórico e Literário para o ano de 1875 (pp. 16, 51, 103). Angra do Heroísmo: Tipografía da Terceira.

Gilbert, E. (2015). Asian Rice in Africa: Plant Genetics and Crop History. In F. BrAY, P. A. CoClanis, E. L. FiEldS-BlaCK \& D. SCHÄFER (Eds.), Rice: Global Networks and New Histories (pp. 212-28). New York: Cambridge University Press.

Gomes, I., QueIroz, A. I. \& Alves, D. (2019). Iberians against Locusts: Fighting CrossBorder Bio-Invaders (1898-1947). Historia Agraria, (78), 127-59.

Hoyle, R. (2017). Britain. In G. Alfani \& C. Ó GRADA (Eds.), Famine in European History (pp.141-65). Cambridge: Cambridge University Press.

Koenning, S. R., Overstreet, C., Noling, J.W., Donald, P. A., Becker, J. O. \& FortNUM, B. A. (1999). Survey of Crop Losses in Response to Phytoparasitic Nematodes in the United States for 1994. The fournal of Nematology, 31 (4S), 587-618.

LangGut, D., Finkelstein, I. \& Litt, T. (2013). Climate and the Late Bronze Collapse: New Evidence from the Southern Levant. Tel Aviv: Fournal of the Institute of Archaeology of Tel Aviv University, 40 (2), 149-75.

Langgut, D., Finkelstein, I., Litt, T., Neumann, F. H. \& Stein, M. (2015). Vegetation and Climate Changes during the Bronze and Iron Ages (3600-600 BCE) in the Southern Levant Based on Palynological Records. Radiocarbon, 57 (2), 217-35.

Leitão, A. N. (1906). A Baçia Hydrografica de Aveiro e a Salubridade Pública (esboço de estudo). Inaugural dissertation, Escola Médico Cirúrgica do Porto. Porto: Imprensa Portuguesa.

Lockwood, J. A. (2009). Beetle Bombs. In J. A. Lockwood, Six Legged soldiers: Using Insects as Weapons of War (pp. 128-38). New York: Oxford University Press.

Macedo, M. (2011). Port Wine Landscape: Railroads, Phylloxera, and Agricultural Science. Agricultural History, 85 (2), 157-73.

Macedo, M. (2012). Da filoxera ao território da agricultura científica: Em Projetar e Construir a Nação. Engenheiros, Ciência e Território em Portugal no século XIX (pp. 24783). Lisboa: Imprensa de Ciencias Sociais.

MARTins, C. A. (1991). A filoxera na viticultura nacional. Análise Social, 26 (112-113), 653-88.

MARTINS, C. A. (1992). Opções económicas e influência política de uma família burguesa oitocentista: O caso de São Romão e José Maria dos Santos. Análise Social, 27 (116117), 367-404. 
Martins, C. A. (1996). A intervenção política dos vinhateiros no século XIX. Análise Social, 31 (136-137), 413-35.

Martins, C. A. (2005). A agricultura. In P. Lains \& A. F. DA Silva (Orgs.), História económica de Portugal, 1700-2000. II: O século XIX (pp. 219-58). Lisboa: Imprensa de Ciencias Sociais.

MAUCH, C. (2009). Introduction. In C. MAUCH \& C. PFISTER (Eds.), Natural Disasters, Cultural Responses: Case Studies toward a Global Environmental History (pp. 1-16). Lanham: Lexington Books.

Melo, C. J. (2017). Arborizar contra cheias, tempestades e marés, 1834-1886: Políticas de águas e de florestas em Portugal. Lisboa: Instituto de Arqueologia e Paleociencias/Instituto de Historia Contemporanea.

MeNDiA, H. C. M. DE (1883). A cultura do arroz no districto de Coimbra. Lisboa: Imprensa Nacional.

MirANDA, S. DE (1989). O ciclo da laranja e os "gentlemen farmers" da Ilha da S.Miguel, 1780-1880. Ponta Delgada: Instituto Cultural de Ponta Delgada.

Ó GradA, C. (2009). Famine: A Short History. Princeton: Princeton University Press.

Ó Grada, C. (2017). Ireland. In G. Alfani \& C. Ó GRAdA (Eds.), Famine in European History (pp. 166-84). Cambridge/New York: Cambridge University Press.

Oerke, E. C. (1999). Estimated Crop Losses due to Pathogens, Animal Pests and Weeds. In E. C. Oerke, H. W. Dehne, F. Schonbeck \& A. Weber (Eds.), Crop Production and Crop Protection: Estimated Losses in Major Food and Cash Crop (pp. 72-88). Amsterdam: Elsevier.

Oliveira, C. M., Auad, A. M., Mendes, S. M. \& Frizzas, M. R. (2014). Crop Losses and the Economic Impact of Insect Pests on Brazilian Agriculture. Crop Protection, (56), 50-4.

Oliver-Smith, A. (1999). "What is a Disaster?": Anthropological Perspectives on a Persistent Question. In A. Oliver-Smith \& S. Hoffman (Eds.), The Angry Earth: Disaster in Anthropological Perspectives (pp. 18-34). New York/London: Routledge.

PANkhurst, R. (1966). The Great Ethiopian Famine of 1888-1892: A New Assessment. Fournal of the History of Medicine and Allied Sciences, 21 (2), 95-124.

PereirA, G. M. (1989). A produção de um espaço regional: O Alto Douro no tempo da filoxera. Revista da Faculdade de Letras. Historia, (6), 311-52.

PFISTER, C. (2009). Learning from Nature-Induced Disasters: Theoretical Considerations and Case Studies from Western Europe. In C. MAUCH \& C. PFISTER (Eds.), Natural Disasters, Cultural Responses: Case Studies toward a Global Environmental History (pp. 17-40). Lanham: Lexington Books.

Pfister, C., Brádzil, R., Luterbacher, J., Ogilvie, A. E. J. \& White, S. (2018). Early Modern Europe. In S. White, C. Pfister \& F. Mauelshagen (Eds.), The Palgrave Handbook of Climate History (pp. 265-98). London: Palgrave Macmillan. 
Pfister, C., Garnier, E., Alcoforado, M. J., Wheeler, D., Luterbacher, J., Nunes, M.F. \& TABorda, J. P. (2010) The Meteorological Framework and the Cultural Memory of Three Severe Winter-Storms in Early Eighteenth-Century Europe. Climatic Change, (101), 281-310.

Post, J. D. (1973). Meteorological Historiography. The fournal of Interdisciplinary History, 3 (4), 721-32.

QueIroz, A. I. \& Alves, D. (2019). Praga e poder: História do "devorista das laranjeiras" (Açores, Portugal, 1840-1860). Análise Social, 54 (231), 226-54.

Ribeiro, O., Lautensach, H. \& Daveau, S. (1987). Geografia de Portugal. IV: A vida económica e social (pp. 1020-22). Lisboa: João Sá da Costa.

Rosenzweig, C., Iglesius, A., Yang, X. B., Epstein, P. R. \& Chivian, E. (2001). Climate Change and Extreme Weather Events: Implications for Food Production, Plant Diseases, and Pests. NASA Publications, (24), 90-104. htp://digitalcommons.unl.edu/ nasapub/24

SEn, A. (1981). Poverty and Famines: An Essay on Entitlement and Deprivation. Oxford: Claredon Press.

SoARes, R. M. (1878). Mémoire sur les vins du Portugal: Carte du Pays vignoble du haut Douro avec indications des points attaqués par les phylloxera. Lisboa: Imprensa Nacional. Sprenger, J. (2015). An Ocean of Locusts: The Perception and Control of Insect Pests in Prussian Brandenburg (1700-1850). Environment and History, 21 (4), 513-36.

TELLES, V. C. S. S. (1800). Memória sobre a cultura do arros em Portugal, e suas conquistas, oferecida a S. Alteza real o principe regente Nosso senhor, publicada por Fr. Fosé Mariano Velloso. Lisboa: Oficina da Casa Litteraria do Arco do Cego.

Thorndycraft, V. R., Benito, G., Barriendos, M. \& Llasat, C. (2003). Paleofloods, Historical Data and Climatic Variability: Applications in Flood Risk Assessment. Madrid: Centro Superior de Investigaciones Científicas/Centro de Ciencias Medioambientales.

VAQuinhas, I. (1996). Violência, justiça e sociedade rural: Os campos de Coimbra, Montemor-o-Velho e Penacova de 1858 a 1918. Porto: Afrontamento.

VIEIRA, V. D. F. (1984). Memória sobre a Vila de Eixo (1868-1869). Boletim Municipal de Aveiro, (3), 30-64.

Wallemace, P. (Coord.) (2018). Economic Losses, Poverty and Disasters 1998-2017. Bruxelles/Genève: Centre for Research on the Epidemiology of Disasters/United Nations Office for Disaster Risk Reduction.

WeBster, J.W. (1821). A Description of the Island of St. Michael: Comprising an Account of Its Geological Structure;With Remarks on the other Azores orWestern Island. Boston: R. P. and C. Williams. 
WeInTRITT, O. (2009). The Floods of Baghdad: Cultural and Technological Responses. In C. MAuch \& C. Pfister (Eds.), Natural Disasters, Cultural Responses: Case Studies toward a Global Environmental History (pp. 165-82). London: Lexington Books. White, S., Brooke, J. \& Pfister, C. (2018). Climate, Weather, Agriculture and Food. In S. White, C. Pfister \& F. Mauelshagen (Eds.), The Palgrave Handbook of Climate History (pp. 331-54). London: Palgrave Macmillan. 